\title{
Neuromedin-U stimulates enucleation-induced adrenocortical regeneration in the rat
}

\author{
MARCIN TREJTER ${ }^{1}$, GIULIANO NERI ${ }^{2}$, MARCIN RUCINSKI $^{1}$, MARIOLA MAJCHRZAK ${ }^{1}$, \\ GASTONE G. NUSSDORFER ${ }^{2 *}$ and LUDWIK K. MALENDOWICZ ${ }^{1}$
}

\author{
${ }^{1}$ Department of Histology and Embryology, Poznan University of Medical Science, PL-60781 Poznan, Poland; \\ ${ }^{2}$ Department of Human Anatomy and Physiology, School of Medicine, University of Padua, I-35121 Padua, Italy
}

Received November 27, 2007; Accepted January 30, 2008

\begin{abstract}
Neuromedin-U (NMU) is a brain-gut peptide, which has been previously found to stimulate hypothalamicpituitary-adrenal axis in the rat. Enucleation-induced adrenal regeneration in rats with contralateral adrenalectomy is a well-established model of adrenal growth, that not only depends on the compensatory ACTH hypersecretion, but is also modulated by several regulatory peptides. Hence, we investigated whether NMU may be included in this group of bioactive molecules. Reverse transcription-polymerase chain reaction and immunocytochemistry showed that regenerating rat adrenocortical cells at days 5 and 8 after surgery express the NMU receptor NMUR1 as mRNA and protein. NMU8 administration to rats bearing regenerating adrenals markedly raised the plasma concentration of corticosterone and notably enhanced proliferative activity of adrenocortical cells. ACTH blood level was unchanged at day 5 and significantly decreased at day 8. The conclusion is drawn that NMU stimulates regeneration of rat adrenal cortex, via a mechanism independent of pituitary ACTH and involving the activation of NMUR1 located on adrenocortical cells.
\end{abstract}

\section{Introduction}

Neuromedin U (NMU) is a brain-gut peptide involved in the regulation of energy homeostasis and neuroendocrine functions. NMU acts via two subtypes of $\mathrm{G}$ protein-coupled receptors, NMUR1 and NMUR2, the former being the peripheral receptor and the latter the central one (reviewed in refs. 1,2). As in the case of other peptides modulating energy homeostasis and food intake (e.g. NPY, cholecystokinin, galanin, leptin, orexins, NPW and beacon) (3-9), also NMU

Correspondence to: Dr Ludwik K. Malendowicz, Poznan University of Medical Sciences, Department of Histology and Embryology, 6 Swiecicki Street, PL-60781 Poznan, Poland

E-mail: 1km@amp.edu.pl

*Deceased

Key words: neuromedin-U, NMUR1, regenerating adrenal cortex, rat appears to regulate the hypothalamic-pituitary-adrenal (HPA) axis (10-16). Since the expression of NMU gene was not detected in the rat adrenal, but adrenocortical cells are provided with NMUR1 $(17,18)$, it is likely that NMU acts on this gland via a classic endocrine route.

Enucleation-induced adrenal regeneration is a classic model of rapid adrenocortical growth $(19,20)$, that is modulated apart from ACTH, by several other regulatory peptides: adrenomedullin, galanin, orexins and arginin-vasopressin have been reported to stimulate, and leptin, enkephalin and perhaps beacon to inhibit adrenal regeneration $(8,23,24)$. Evidence has been recently provided that NMU8, that contains the 7-amino acid C-terminal active sequence of the native 23-amino acid peptide (25), enhances proliferation of immature rat adrenocortical cells in primary culture (18). Hence, it seemed worthwhile to investigate the expression of NMUR 1 in and the effects of NMU8 administration on the regenerating rat adrenal cortex.

\section{Materials and methods}

Animals and reagents. Female Wistar rats (final body weight 100-110 g) were kept under a $14: 10$ h light-dark cycle (illumination onset at 6:00 a.m.) at $23^{\circ} \mathrm{C}$, and maintained under a standard diet and tap water ad libitum. The study protocol was approved by the local Ethics Committee for Animal Studies. NMU8 was purchased from Bachem (Bubbendorf, Switzerland), and vincristine from Gedeon-Richter (Budapest, Hungary). Rabbit anti-rat NMUR1 polyclonal primary antibody was provided by Alpha Diagnostic International (San Antonio, TX), and secondary peroxidase-conjugated anti-rabbit IgG polyclonal antibodies by Amersham Biosciences (Piscataway, $\mathrm{NJ})$. All other chemicals and reagents were obtained from Sigma-Aldrich Corp. (St. Louis, MO).

Experimental design. Under ether anesthesia and via dorsal approach, the left adrenal gland was enucleated and the contralateral gland removed (22). A group of animals was sham-operated (intact adrenals). Rats were sacrificed 5 or 8 days after surgery, and their intact or regenerating adrenals were removed. Specimens were partly frozen at $-80^{\circ} \mathrm{C}$ for reverse transcription (RT)-polymerase chain reaction (PCR) assay $(n=6)$, and partly fixed in Bouin's solution and embedded in paraffin for immunocytochemistry (ICC). Other rats bearing 
regenerating adrenals were divided into two experimental groups $(n=8)$. One group was given three subcutaneous injections of $1.5 \mathrm{nmoles} / 100 \mathrm{~g}$ body weight of NMU8 dissolved in $0.2 \mathrm{ml} 0.9 \%$ saline 24,16 and $8 \mathrm{~h}$ before sacrifice. The other group (control rats) received subcutaneous injection of vehicle. Three hours before sacrifice all rats were given an intraperitoneal injection of $0.1 \mathrm{mg} / 100 \mathrm{~g}$ body weight of vincristine. Animals were decapitated at 11:00 a.m., and their trunk blood was collected in the presence of $1 \mathrm{mg} / \mathrm{ml}$ EDTA. Plasma was separated and stored at $-36^{\circ} \mathrm{C}$ for hormone assay. Regenerating adrenals were removed and processed for light microscopy for metaphase-index assay and morphometric estimations.

$R T-P C R$. Total RNA was extracted from the frozen specimens, and reverse transcribed to cDNA (26-29). PCR was carried out, as previously detailed (30-33), in a Roche LightCycler 2.0, using the following primers: NMUR 1 sense (481-500), 5'-GCCATCTGGGTCTTCGCTAT-3' and antisense (797-816), 5'-CACCTGTCTGCGTTCCCTAT-3' (336 bp; accession number, AF242873). The PCR program was: denaturation step at $94^{\circ} \mathrm{C}$ for $10 \mathrm{~min}$, followed by 35 cycles of three amplification steps $\left(94^{\circ} \mathrm{C}\right.$ for $30 \mathrm{sec}$, annealing at $55^{\circ} \mathrm{C}$ for $60 \mathrm{sec}$ and extension at $68^{\circ} \mathrm{C}$ for $120 \mathrm{sec}$ ). To rule out the possibility of amplifying genomic DNA, one PCR was performed without prior RT of the RNA. Detection of the PCR amplification products was carried out by size fractionation on $2 \%$ agarose gel electrophoresis.

ICC. Paraffin-embedded regenerating adrenals were cut, and the sections $(6 \mu \mathrm{m})$ were incubated with the primary anti-NMUR 1 antibody $\left(1: 100\right.$ dilution) for $60 \mathrm{~min}$ at $4^{\circ} \mathrm{C}$. After washing, section were then incubated overnight at $37^{\circ} \mathrm{C}$ with the secondary peroxidase-conjugated antibody, and peroxidase activity was detected using the DAB technique (Dako Liquid DAB substrate-chromogen system; Dako, Glostrup, Denmark). When necessary, nuclei were counterstained with hematoxylin. Negative controls were carried out by similarly treating adjacent sections and omitting the primary antibody (34).

Metaphase index and morphometry. Sections $(6 \mu \mathrm{m})$ were stained with hematoxylin and eosin, and metaphase index (number of vincristine-arrested metaphase cells per 1,000 cells) was calculated at a magnification of $x 400$, by counting 5,000 cells in the outer cortex of each regenerating adrenal parenchyma (24). The number of nuclei of adrenocortical cells was counted at a magnification of $x 400$ in 50 fields (area, $0.003 \mathrm{~mm}^{2}$ ) of the outer cortex of each regenerating adrenal, and the number of nuclei per $\mathrm{mm}^{2}$ was calculated.

Hormone assay. ACTH aldosterone and corticosterone were extracted from plasma, and measured by RIA, as detailed earlier $(51,52)$. Aldosterone RIA: sensitivity, $5 \mathrm{pg} / \mathrm{ml}$; intraand interassay $\mathrm{CVs}, 5$ and $7 \%$, respectively. Corticosterone RIA: sensitivity, $50 \mathrm{pg} / \mathrm{mL}$; intra- and interassay CVs, 7 and $9 \%$, respectively.

Statistics. Data were expressed as means \pm SEM, and the statistical significance of the differences among experimental

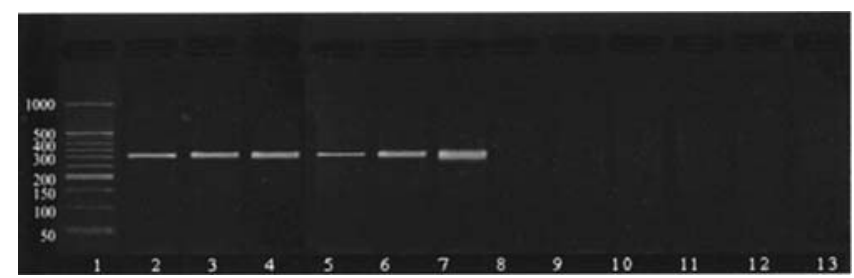

Figure 1. Ethidium bromide-stained $2 \%$ agarose gel showing cDNA amplified with rat NMUR1 specific primers from exemplary intact adrenal cortexes (2 and 3), and regenerating adrenals at day 5 (4 and 5) and day 8 after surgery (6 and 7): Respective negative controls (no RT of the RNA) are shown in lanes 8-13. Lane 1 was loaded with $200 \mathrm{ng}$ of a DNA size marker (50 bp DNA Ladder; MBI Fermentas, Vilnius, Lithuania).

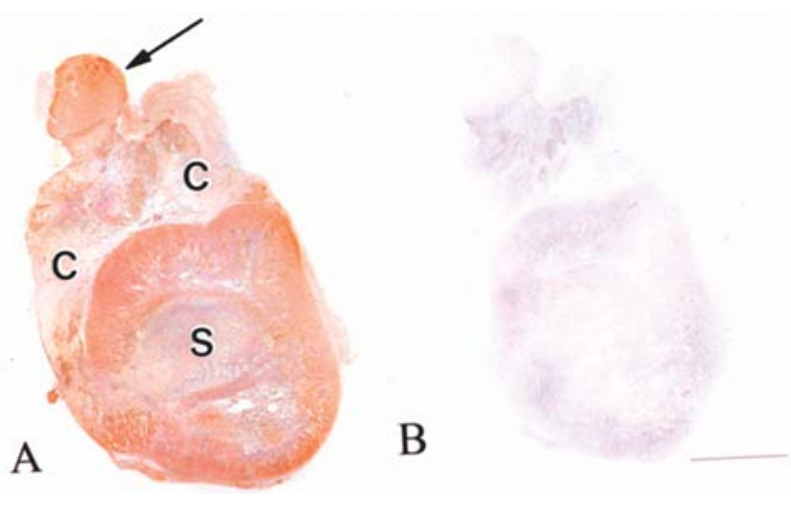

Figure 2. (A) ICC localization of NMUR1-like immunoreactivity in the regenerating rat adrenal gland at day 8 after surgery. Staining is seen in the narrow cortex rim around the central scar (S) and in islets of adrenocortical cells (arrow) outside the connective capsule (C). (B) Negative control was obtained by omitting the primary antibody. Magnification as defined by bar, $1 \mathrm{~mm}$.

groups was estimated using ANOVA, followed by the Duncan's multiple range test.

\section{Results}

RT-PCR detected the expression of NMU1 mRNA in intact adrenal cortex of sham-operated rats and regenerating adrenals at days 5 and 8 after surgery (Fig. 1). ICC showed the presence of NMUR1-like immunoreactivity in the narrow band of regenerating cortex, as well as in small islets of adrenocortical cells located outside the connective capsule (Fig. 2).

NMU8 administration decreased ACTH plasma level at day 8 of regeneration, did not affect aldosterone blood concentration, and markedly raised the level of circulating corticosterone at days 5 and 8 after surgery (Fig. 3). NMU8 treatment enhanced proliferative activity of regenerating adrenals at day 5 after surgery, and increased the number of adrenocortical cells per unit area at day 8 (Fig. 4).

\section{Discussion}

The growth of the adrenal cortex during the early stages of regeneration can be divided into two phases: a differentiation period from days 0 to 3 , and a high proliferation period from days 4 to 7 ; starting from day 8 the proliferative activity starts 

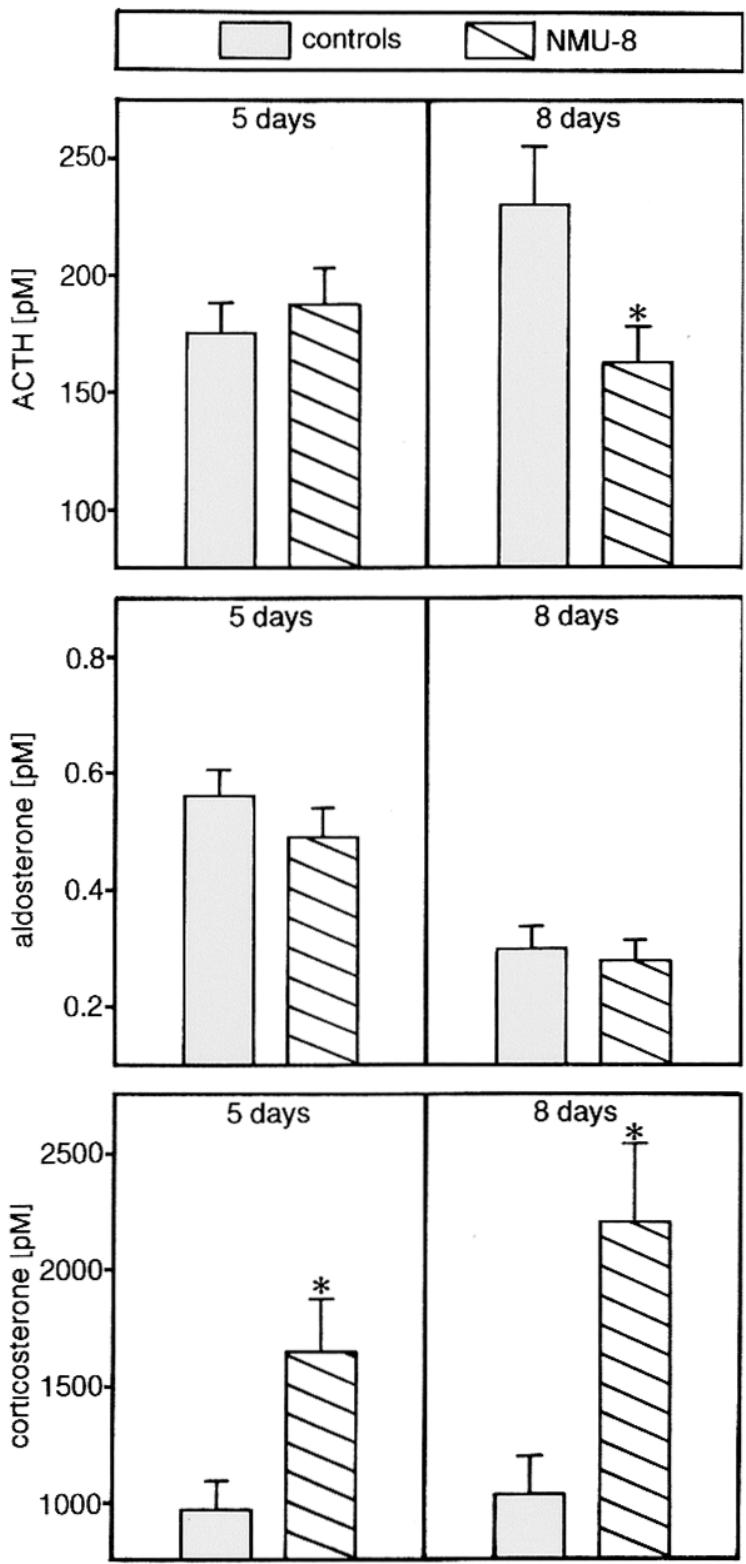

Figure 3. Effects of NMU8 administration on hormone plasma concentrations in rats bearing regenerating adrenals at days 5 and 8 after surgery. Bars are means \pm SEM $(n=8)$. ${ }^{*} \mathrm{P}<0.05$ from control group. Values in sham-operated rats are: ACTH, 18-20 pM; aldosterone, 300-330 pM; and corticosterone, $80-90 \mathrm{nM}$.

to decrease (37). This type of adrenocortical growth resembles that occurring during early stages of organogenesis, and primarily depends on the hypersecretion of ACTH and other POMC-derived peptides ensuing from the decreased production of glucocorticoid hormones by the reduced mass of regenerating parenchyma. Optimal regeneration requires contralateral adrenalectomy because glucocorticoid secretion from the remaining intact adrenal prevents the increased ACTH secretion. As compared to sham-operated rats, animals bearing regenerating adrenals possess blood levels of ACTH $\sim 10$-fold higher and of corticosterone markedly lower due to the reduced mass of secreting tissue. However, the synthetic glucocorticoid dexamethasone was found to inhibit adrenocortical cytogenesis in intact gland, but not in enucleationinduced regenerating adrenals (44-48), suggesting that, in

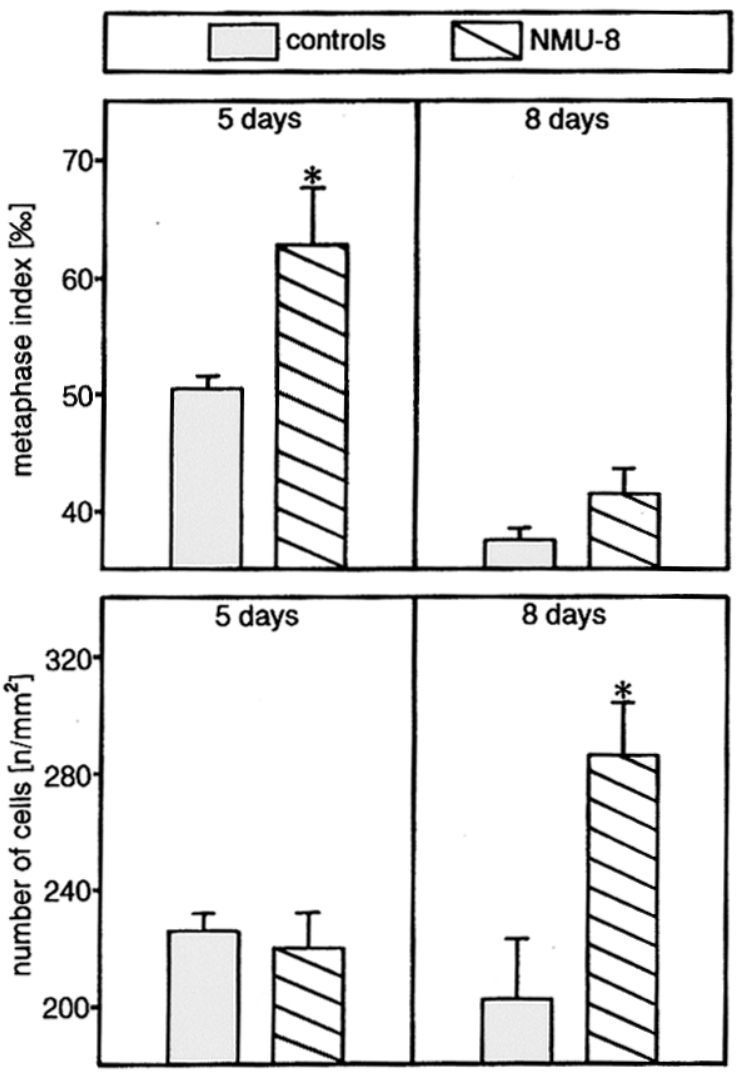

Figure 4. Effects of NMU8 administration on the growth of regenerating rat adrenal cortex at days 5 and 8 after surgery. Bars are means \pm SEM $(n=6)$. ${ }^{*} \mathrm{P}<0.05$ from control group.

addition to ACTH, other factors control adrenal regeneration. Some of these extra-pituitary ACTH factors may derive from the nervous system $(19,38,41,43)$, while others may be represented by several regulatory peptides acting via a classic endocrine route or in a paracrine-autocrine manner (see Introduction).

Our present findings indicate that NMU may be included in the group of regulatory peptides acting as circulating hormones, and this contention is based on the following pieces of evidence: i) NMU is not expressed in adrenal cortex $(17,18)$, but regenerating adrenocortical cells are provided with NMUR1, ii) the repeated subcutaneous administration of NMU enhances neocytogenesis in the regenerating adrenals during the period of their high proliferative activity (day 5), and markedly stimulates glucocorticoid secretion at both day 5 and 8 after surgery; and iii) NMU treatment does not affect the blood concentration of ACTH at day 5, and at day 8 decreases it, thereby ruling out the possibility that the secretion and growth promoting effects of the peptide may depend on the stimulation of the central branch of the HPA axis.

This last observation is in contrast to the earlier findings obtained in adult rats with intact adrenals, where NMU either centrally or peripherally administered has been reported to enhance ACTH and corticosterone secretion (10-16). It is conceivable that the notable compensatory ACTH hypersecretion occurring during adrenal regeneration in contralaterally adrenalectomized rats may prevent or mask the slight NMU stimulating affect on hypothalamic-pituitary CRH-ACTH release. Moreover, the NMU-induced sizeable 
decrease in ACTH blood level at day 8 of regeneration could be connected to the marked 2.5-fold rise in corticosterone plasma level quenching the negative feed-back mechanism driving ACTH hypersecretion.

Earlier studies carried out in adult rats provided evidence that NMU effects adrenocortical cells, at least partly, mediated by a paracrine mechanism involving CRH-ACTH intramedullary system $(10,11)$, as occurs for other adrenocortical secretagogue peptides such as interleukin-1B and PACAP (reviewed in ref. 49). NMUR1 mRNA was detected in rat adrenal medulla (18), and NMU was found to increase in the rat the blood concentration of catecholamines (50), which are known to regulate adrenal cortex growth and secretion (18). However, in enucleation-induced adrenal growth, regeneration of medullary cells occurs only at the later stages of organ healing, and therefore this indirect paracrine route of NMU action at days 5 and 8 after adrenal enucleation seems very unlikely if not impossible $(20,51)$.

Collectively, our present findings allow us to conclude that NMU stimulates regeneration of rat adrenal cortex, through a mechanism independent of pituitary ACTH and involving NMUR1 located on adrenocortical cells.

\section{References}

1. Brighton PJ, Szekeres PG and Willars GB: Neuromedin U and its receptors: structure, function, and physiological roles. Pharmacol Rev 56: 231-248, 2004.

2. Jathwa PH, Small CJ and Bloom SR: Neuromedin-U (NMU): brain peptide. In: Handbook of Biologically Active Peptides. Kastin AJ (ed). Academic Press, Burlington, pp745-752, 2006.

3. Spinazzi R, Andreis PG and Nussdorfer GG: Neuropeptide Y and Y-receptors in the autocrine-paracrine regulation of adrenal gland under physiological and pathophysiological conditions (Review). Int J Mol Med 15: 3-13, 2005.

4. Nussdorfer GG, Spinazzi R and Mazzocchi G: Cholecystokinin (CCK) and adrenal cortex secretion. Vitam Horm 71: 433-453, 2005.

5. Rucinski M, Spinazzi R, Ziolkowska A, Nussdorfer GG and Malendowicz LK: Effects of beacon on the rat pituitaryadrenocortical axis response to stress. Int J Mol Med 16: 297-299, 2005.

6. Spinazzi R, Andreis PG, Rossi GP and Nussdorfer GG: Orexins in the regulation of the hypothalamic-pituitary-adrenal axis. Pharmacol Rev 58: 46-57, 2006.

7. Hochól A, Tortorella C, Rucinski M, Ziolkowska A, Nussdorfer GG and Malendowicz LK: Effects of neuropeptides B and $\mathrm{W}$ on the rat pituitary-adrenocortical axis: in vivo and in vitro studies. Int J Mol Med 19: 207-211, 2007.

8. Malendowicz LK, Rucinski M, Belloni AS, Ziolkowska A and Nussdorfer GG: Leptin and the regulation of the hypothalamicpituitary-adrenal axis. Int Rev Cytol 263: 65-104, 2007.

9. Tortorella C, Neri G and Nussdorfer GG: Galanin in the regulation of the hypothalamic-pituitary-adrenal axis (Review). Int J Mol Med 19: 639-647, 2007.

10. Malendowicz LK, Andreis PG, Markowska A, Nowak M, Warchol JB, Neri G and Nussdorfer GG: Effects of neuromedin U-8 on the secretory activity of the rat adrenal-cortex: evidence for an indirect action requiring the presence of the zona medullaris. Res Exp Med 194: 69-79, 1994.

11. Malendowicz LK, Nussdorfer GG, Markowska A, Tortorella C, Nowak M and Warchol JB: Effects of neuromedin-U (NMU)-8 on the rat hypothalamo-pituitary-adrenal axis: evidence of a direct effect of NmU-8 on the adrenal-gland. Neuropeptides 26: 47-53, 1994.

12. Malendowicz LK: Role of neuromedins in the regulation of adrenocortical function. Horm Metab Res 30: 374-384, 1998.

13. Ozaki Y, Onaka T, Nakazato M, Saito J, Kanemoto K, Matsumoto T and Ueta Y: Centrally administered neuromedin $\mathrm{U}$ activates neurosecretion and induction of C-Fos messenger ribonucleic acid in the paraventricular and supraoptic nuclei of rat. Endocrinology 143: 4320-4329, 2002.
14. Wren AM, Small CJ, Abbott CR, Jethwa PH, Keneddy AR, Murphy KG, Stanley SA, Zollner AN, Ghatei MA and Bloom SR: Hypothalamic actions of neuromedin U. Endocrinology 143: 4227-4234, 2002

15. Thompson EL, Murphy KG, Todd JF, Martin NM, Small CJ, Ghatei MA and Bloom SR: Chronic administration of NMU into the paraventricular nucleus stimulates the HPA axis but does not influence food intake or body weight. Biochem Biophys Res Commun 323: 65-71, 2004.

16. Ueta Y, Ozaki Y and Saito J: Novel G-protein coupled receptor ligands and neurohypophysial hormones. J Neuroendocrinol 16: 378-382, 2004.

17. Rucinski M, Ziolkowska A, Neri G, Trejter M, Zemleduch T, Tyczewska M, Nussdorfer GG and Malendowicz LK: Expression of neuromedin $\mathrm{S}$ and $\mathrm{U}$ and their receptors in the hypothalamus and endocrine glands of the rat. Int J Mol Med 20: 255-259, 2007.

18. Ziolkowska A, Macchi C, Trejter M, Rucinski M, Nowak M, Nussdorfer GG and Malendowicz LK: Effects of neuromedin-U on Immature rat adrenocortical cells: in vitro and in vivo studies. Int J Mol Med (In press).

19. Dallman MF: Control of adrenocortical growth in vivo. Endocr Res 10: 213-242, 1985.

20. Nussdorfer GG: Cytophysiology of the adrenal cortex. Int Rev Cytol 98: 1-405 1986.

21. Trejter M, Carraro G, Rucinski M, Hóchol A, Rebuffat P, Nussdorfer GG and Maledowicz LK: Arginin-vasopressin regulate proliferative activity of the regenerating rat adrenal cortex. Int J Mol Med 15: 993-997, 2005.

22. Rebuffat P, Macchi C, Malendowicz LK and Nussdorfer GG: Up-regulation of adrenomedullin receptor gene expression in activated local stem cells during rat adrenal regeneration. Int $\mathrm{J}$ Mol Med 20: 855-858, 2007.

23. Malendowicz LK, Rebuffat P, Tortorella C, Nussdorfer GG, Ziolkowska A and Hochol A: Effects of met-enkephalin on cell proliferation in different models of adrenocortical-cell growth. Int J Mol Med 15: 841-845, 2005.

24. Ziolkowska A, Rucinski M, Tyczewska M, Belloni AS, Nowak M, Nussdorfer GG and Malendowicz LK: Down-regulation of the beacon gene expression in the regenerating rat adrenal cortex. Peptides 27: 3216-3219, 2006.

25. Minamino N, Kangawa K and Matsuo M: Neuromedin U-8 and U-25: novel uterus stimulating and hypertensive peptides identified in porcine spinal cord. Biochem Biophys Res Commun 130: 1078-1085, 1985.

26. Albertin G, Ruggero M, Guidolin D and Nussdorfer GG: Gene silencing of humana RAMP2 mediated by short-interfering RNA. Int J Mol Med 18: 531-535, 2006.

27. Carraro G, Albertin G, Aragona F, Forneris M, Casale V, Spinazzi R and Nussdorfer GG: Age-dependent decrease in the ghrelin gene expression in the human adrenal cortex: a real-time PCR study. Int J Mol Med 17: 319-321, 2006.

28. Spinazzi R, Albertin G, Nico B, Guidolin D, Di Liddo R, Rossi GP, Ribatti D and Nussdorfer GG: Urotensin-II and its receptor (UT-R) are expressed in rat brain endothelial cells, and urotensin-II via UT-R stimulates angiogenesis in vivo and in vitro. Int J Mol Med 18: 1107-1112, 2006.

29. Rossi GP, Sticchi D, Giuliani L, Bernante P, Zavattero S, Pessina AC and Nussdorfer GG: Adiponectin receptor expression in the human adrenal cortex and aldosterone-producing adenomas. Int J Mol Med 17: 975-980, 2006.

30. Albertin G, Casale V, Ziolkowska A, Spinazzi R, Malendowicz LK, Rossi GP and Nussdorfer GG: Urotensin-II and UII-receptor expression and function in the rat adrenal cortex. Int J Mol Med 17: 1111-1115, 2006.

31. Malendowicz LK, Rucinski M, Belloni AS, Ziolkowska A, Nussdorfer GG and Kwias Z: Real-time PCR analysis of leptin and leptin receptor expression in the rat prostate, and effects of leptin on prostatic acid phosphatase release. Int J Mol Med 18: 1097-1100, 2006

32. Rucinski M, Ziolkowska A, Hochol A, Pucher A, Macchi C, Belloni AS, Nussdorfer GG and Malendowicz LK: Estradiol and resveratrol stimulating effect on osteocalcin, but not osteonectin and collagen- $1 \alpha$ gene expression in primary culture of rat calvarial osteoblast-like cells. Int J Mol Med 18: 565-570, 2006.

33. Ziolkowska A, Tortorella C, Nussdorfer GG, Rucinski M, Majchrzak M and Malendowicz LK: Accumulation of steroidogenic acute regulatory protein mRNA and decrease in the secretory and proliferative activity of rat adrenocortical cells in the presence of proteasome inhibitors. Int J Mol Med 17: 865-868, 2006. 
34. Hochol A, Belloni AS, Rucinski M, Ziolkowska A, Di Liddo R, Nussdorfer GG and Malendowicz LK: Expression of neuropeptides $\mathrm{B}$ and $\mathrm{W}$ and their receptors in endocrine glands of the rat. Int J Mol Med 18: 1101-1106, 2006.

35. Hochol A, Albertin G, Nussdorfer GG, Spinazzi R, Ziolkowska A, Rucinski M and Malendowicz LK: Effects of neuropeptides B and $\mathrm{W}$ on the secretion and growth of rat adrenocortical cells. Int J Mol Med 14: 843-847, 2004.

36. Spinazzi R, Petrelli L, Guidolin D, Carraro G, Casale V, Tortorella C, Neri G, Albertin G, Andreis PG and Nussdorfer GG: In vitro culture on Matrigel favors the long-term maintenance of rat zona glomerulosa-cell differentiated phenotype. Int J Mol Med 17: 1101-1110, 2006.

37. Taki TM and Nickerson PA: Differentiation and proliferation of adrenocortical cells during the early stages of regeneration. Lab Invest 53: 91-100, 1985 .

38. Estivariz FE, Morano MI, Carino M, Jackson S and Lowry PJ: Adrenal regeneration in the rat is mediated by mitogenic $\mathrm{N}$-terminal pro-opiomelanocortin peptides generated by changes in precursor processing in the anterior pituitary. $\mathrm{J}$ Endocrinol 116: 207-216, 1988.

39. Sarria L, Losada J and Bueno-Lopez JL: Immunohistochemical analysis of adrenal proliferation and corticosterone expression in experimental adrenal regeneration. Histol Histopathol 10: 603-609, 1995.

40. Mitani F, Mukai K, Miyamoto H, Suematsu M and Ishimura Y: Development of functional zonation in the rat adrenal cortex. Endocrinology 140: 3342-3353, 1999.

41. Ulrich-Lai YM and Engeland WC: Hyperinnervation during adrenal regeneration influences the rate of functional recovery. Neuroendocrinology 71: 107-123, 2000.

42. Hochol A, De Caro R, Jedrzejczak N, Trejter M, Nussdorfer GG and Malendowicz LK: Effect of pentagastrin on steroid secretion and proliferative activity of regenerating rat adrenal cortex. Cytobios 106: 119-124, 2001.
43. Ulrich-Lai YM, Fraticelli AI and Engeland WC: Capsaicinsensitive nerve ribers: A potential extra-ACTH mechanism participating in adrenal regeneration in rats. Microsc Res Tech 61: 252-258, 2003.

44. Stachowiak A, Nussdorfer GG and Malendowicz LK: Proliferation and distribution of adrenocortical cells in the gland of ACTH- or dexamethasone-treated rats. Histol Histopathol 5: 25-29, 1990.

45. Lesniewska B, Nowak KW and Malendowicz LK: Dexamethasone-induced adrenal cortex atrophy and recovery of the gland from partial, steroid-induced atrophy. Exp Clin Endocrinol 100: 133-139, 1992.

46. Perone MJ, Chisari AN, Gomez Dumm CL, Spinedi E and Estivariz FE: Bilateral adrenal enucleation-induced changes in adenohypophyseal pro-opiomelanocortin (POMC)- related peptides synthesis and secretion: a comparative study with adrenalectomized rats. J Endocrinol Invest 20: 172-182, 1997.

47. Engeland WC and Levay-Young BK: Changes in the glomerulosa cell phenotype during adrenal regeneration in rats. Am J Physiol 276: R1374-R1382, 1999.

48. Malendowicz LK, Trejter M, Rebuffat P, Ziolkowska A, Nussdorfer GG and Majchrzak M: Effects of some endocrine disruptors on the secretory and proliferative activity of the regenerating rat adrenal cortex. Int J Mol Med 18: 197-200, 2006.

49. Chu C, Jin Q, Kunitake T, Kato K, Nabekura T, Nakazato M, Kangawa $\mathrm{K}$ and Kannan $\mathrm{H}$ : Cardiovascular actions of central neuromedin U in conscious rats. Regul Pept 105: 29-34, 2002.

50. Nussdorfer GG: Paracrine control of adrenal cortical function by medullary chromaffin cells. Pharmacol Rev 48: 495-530, 1996.

51. Kmiec B: Histological and histochemical studies on the regeneration of the adrenal medulla after its enucleation in white rats. Folia Morphol 27: 259-268, 1968. 